\title{
Challenging the Soft Power Analysis
}

A Case Study of African Students in the Gülen movement's Turkey

\section{Gabrielle Angey-Sentuc}

\section{(2) OpenEdition}

Journals

\section{Electronic version}

URL: http://journals.openedition.org/ejts/5254

DOI: $10.4000 /$ ejts.5254

ISSN: $1773-0546$

Publisher

EJTS

Electronic reference

Gabrielle Angey-Sentuc, "Challenging the Soft Power Analysis », European Journal of Turkish Studies

[Online], 21 | 2015, Online since 02 March 2016, connection on 16 February 2020. URL : http://

journals.openedition.org/ejts/5254; DOI : 10.4000/ejts.5254

This text was automatically generated on 16 February 2020.

(C) Some rights reserved / Creative Commons license 


\title{
Challenging the Soft Power Analysis
}

\author{
A Case Study of African Students in the Gülen movement's Turkey \\ Gabrielle Angey-Sentuc
}

\section{Introductory remarks}

1 In March 17 2013, the first advisor for the Ministry of Foreign Affairs, Naci Koru (belonging to the AKP majority), declared that the Turkish schools [part of the Gülen Movement, a religiously inspired Turkish movement] were the main actor of Turkish foreign policy in the world (Zaman, 17 mars 2013). Nine months later, the conflict between the Erdoğan government and the Gülen Movement reached its zenith on December 17, 2013, when a Turkish public prosecutor filed a case for corruption against personalities close to the AKP government (including sons of ministers). The Prime Minister Recep Tayyip Erdoğan (President of the Turkish Republic since August 2014) accused the Gülen Movement of being the dark force behind this case ${ }^{1}$. Consequently, the official discourse of the Turkish minister of education dramatically changed. From acknowledging the role of the Turkish schools as a positive actor for Turkey's cultural influence, the discourse shifted to a denunciation of the actions of the Turkish schools in the world as a danger, blaming them for indoctrinating students all over the world, and stating that they should instead become Turkish state-controlled (Maasho 2015). As one of the most striking sign of this disavowal, the Turkish minister of education took back its support from one of the most followed events of the year in the Turkish media: The Turkish Olympiad, organized by associations openly belonging to the Gülen Movement in which children from all over the world, schooled in Gülen schools abroad (known as Turkish schools) would come in Istanbul to perform Turkish poetry, songs and folkloric dances as a testimony to Turkey's growing influence abroad.

What appears behind this surprising shift of public discourse concerning the Gülen Movement's schools is the idea, taken for granted, of their strong influence (positive or negative according to one's political orientation) on Turkey's image beyond its borders. In this article, we will question the concept of soft power with regards to the concrete 
consequences of the educational action of the Turkish Muslim Movement, the Gülen Movement in Sub-Saharan Africa.

\section{The Gülen Movement: an overview}

3 The Gülen Movement (GM) is a Muslim group formed at the end of the 1960's in Turkey whose discourse focuses on the social commitment of its followers to "service" for humanity (hizmet in Turkish, which is the name its members use to describe the Gülen Movement as a whole) ${ }^{2}$. Built around the charismatic personality of Fethullah Gülen, a Turkish preacher who currently resides in the USA, the movement is inspired by Sufi writings, and particularly the neo-Sufi Nurcu group (the followers of Saïd Nursi). This religious tradition focuses on education which is considered a way to combine modern reasoning and religious faith thus good morality in order to preserve a threatened Islamic civilization. Fethullah Gülen became famous in the 1970's for the charismatic speeches he was giving as an imam in Izmir. During this period, a small number of university students started constituting this group, organizing reading camps within a military atmosphere. In the next decades, this growing number of individuals organized in religious, educational, financial (Asya Finans), business (with the businessmen association TUSKON) and media institutions (with several press and TV media groups) connected in a vast network with a great capacity to mobilize both human and financial resources. The network used the phases of the political opening of Turkish politics (such as in the 80's when Özal's Motherland party's [ANAP] government and the Gülen movement started to collaborate in the framework of economic liberalization) in order to expand, and tried to lay low during the repressive periods (in 1980 the Gülen Movement supported the military coup trying to show his pro-state vision, but was still persecuted). In 1999, officially for health reasons but linked to trouble with the Turkish judiciary, Fethullah Gülen fled to the USA. Yet in 2002, the arrival of the AKP (the Justice and Development Party, a right wing conservative party) as a governing party opened a new phase of collaborations between these two actors both inside and outside Turkey. Consequently, Ankara relied upon the Gülen movement as a resource for its international opening.

Indeed, the followers of this faith-based movement created a tremendous network around the world. The network of schools dramatically expanded over the past 20 years, starting with Central Asia (Balc1 2003) at the beginning of the 1990's, Africa and the Balkans in the second-half of the 90s and the USA and Europe from the end of the 90s (Van Bruinenssen 2014). Turks started establishing schools in Africa from 1996 onwards, opening schools in more than 40 sub-Saharan countries.

The peculiarity of the Gülen movement, a successful national and transnational religious enterprise, has been widely studied by academics. A first trend of the literature on the Gülen Movement (Yavuz, Esposito 2003; Yavuz 2003; Özdalga 2000, 2005; Turam 2007) in terms of civil society, focuses on the way the Gülen Movement as a religious group can be a democratizing power in Turkey. These authors tend to draw the genealogy of the movement to locate it in the religious and political context of Turkey. A second trend (Balc1 2003; Tittensor 2014) characterizes the Gülen movement as a religious organization by inserting it into the framework of globalization. These authors refer to the idea of mission in order to describe the educational activities of this religious movement worldwide. A third trend (Agai 2004; Hendrick 2012, 2013), 
more centered on a sociology of the movement in itself, implements an organizational analysis describing its functioning from the inside. These authors try to explain the dynamics of commitment in the movement and the way its structure evolves according to the different social contexts. This article follows the third trend, focusing on a sociological analysis of the Gülen movement as an institution. Yet it attempts to fill in a gap in these works by introducing the point of view of the recipients in a dynamic manner to understand what the Gülen movement as an institution represents for the actors (Turkish or African): their interactions are what constitutes the concrete experience of the Gülen movement, on a daily basis ${ }^{3}$.

\section{The Gülen Movement between Turkey and sub-Saharan Africa}

6 Different reasons explain the strong educative investment of the Gülen movement in sub-Saharan Africa. Religiously speaking, Africa is perceived by the followers as a poor continent both economically and morally, necessitating the help of teachersmissionaries willing to fight against "poverty, ignorance, and intolerance ". In this sense, the followers implement a liberal conception of education in Africa focusing on the elite's formation (Angey forthcoming). What's more, Africa is a continent with a strong economic potential arousing the interest of emerging countries like China, Brazil and Turkey. In Turkey, businessmen close to the Hizmet work hand in hand with the Turkish teachers to open schools (L'Afrique... 2011). These educational activities by Turkish actors in Sub-Saharan Africa have also been encouraged in the framework of the Turkish opening to Africa betting on the economic potential of Turkish-African exchanges almost nonexistent until the beginning of the 1990's relying upon the initiatives of private actors such as the Gülen Movement (Angey 2014). Africa has for long been a land of experimentation for hybrid forms of religious enterprises both exterior and local. As such, this article is part of a wider literature concerning transnational religious enterprises in Africa which both "transcend national boundaries and reinvent 'nations' that have authority to provide matrices of universality" (Fourchard, Mary, Otayek 2005), thus questioning the authority of states to structure the circulation of its citizens. Among these transnational religious enterprises, a few networks such as Aga Khan (Daftary 2003) and the Gülen movement have been successful in opening elite schools targeting rich students.

7 Part of the students of the Turkish schools in Africa (whose proportion varies according to the social context, the financial strength of the movement in this country, and the educative opportunities provided to the nationals there) decide to pursue University studies in Turkey. Is it the success of what is often called "Turkish soft power"?

\section{Purpose and argument}

8 According to Nye, soft power relies upon attractiveness, as a means to shape what the other wants in a sense that is convenient without having to resort to coercion or payoffs (Nye 1990). My article will focus on education, which constitutes an element of Nye's soft power definition. The soft power literature concerning Turkey rather tends to focus on diplomacy and business since Turkey as an emerging country had not been until lately an important education center in the world. The literature on Turkish foreign influence often uses "soft power" without a critical view. It can be presented as a synonym of "diplomacy" as opposed to "military power" (Çandar 2009) that reduces 
the scope of the definition given by Nye. In other cases, it is used in a normative manner (soft power is seen as the power of a democratized, economically open Turkey whose ability to combine Islam and democracy is seen as an inspiration by Arab countries) without questioning the power balances hidden behind this concept (Altunışık 2008). In this sense the contribution of Kerem Öktem and Yohanan Benhaïm (in this EJTS issue) shows the political stakes of labelling soft power in Turkey.

Through a concrete case study focusing on one aspect of Turkish influence beyond its borders, higher education, this article calls into question the relevance of the use of the concept of soft power in the studies focusing on Turkish initiatives towards foreign countries. Nye (2005) used higher education as an exemplary resource of attraction. In his book Soft Power: The Means to Success in World Politics (2004), Nye focuses on types of attraction that can develop soft power. According to him, the three main vectors of soft power are culture, foreign policy and political values. He divides culture between high culture (education, art, literature), addressing the elites, and popular culture, addressing mass entertainment.

In this perspective, our theoretical criticism of the concept of soft power will be structured around 3 points.

11 First of all, according to Nye, education is a source of soft power, understood as attractiveness, as a way to shape others' desires. Students who come and study in a country would keep a close link with the country they studied in which would in turn be useful for the country of reception, when those students take over positions of power in the economy or the political sphere of their own society (Nye 2005). Consequently, many academics convey this type of idea as an obvious truth, without testing it. We are not denying the possibility for an experience of educational socialization in a country to have a consequence over one person's trajectory, making him more sympathetic with the country. Yet empirical evidence must be gathered in order to confirm this hypothesis. Indeed, as Stuart Hall's famous case study focusing on the encoding and decoding of media messages shows, we know that emitting a message or putting in motion an action does not mean it is going to be taken for granted by those who receive it (Hall 1973). In this case, my criticism would focus on the obvious idea that African students schooled in Turkey will be part of the rapprochement between Turkey and the African continent. This idea cannot be asserted as a generality without any proper ethnographic study. Studying the "decoding" by African students of the Gülen Movement's objectives is a way to reintroduce the recipients into the equation, and thus refuse along with Michel de Certeau to consider them as passive. Consequently, I intend to study the "arts de faire", the inventive tactics of the African students as "the ingenious ways in which the weak make use of the strong, thus lend[ing] a political dimension to everyday practices" (Certeau 1984: XVIII).

The second set of criticism focuses on the unclear conceptualization of the relation between public and private actors in the soft power theory. In Nye's theory, it seems that the action of private actors will necessarily go in the way of a wider national soft power. Or whenever it goes the other way, Nye just seems to give both private and state actors the possession of different soft powers without going further. The soft power concept thus fails to describe the complexity of situations of expansion of public and private actors outside Turkey and the complicated conflictual, negotiated, supportive, "discharged" (Hibou 1999) type of relations that exist between them. 

theory. The fact that a country is capable of bringing students from foreign countries to its universities is analysed as one of the main proofs of a country's attractiveness, a sign of a country's strength. Yet, from the African students' point of view, educational choices are entailed in a field of possibilities ("champ des possibles" in French). Taking into account the national, cultural, historical and economic frames in African students' choices is necessary to produce a rigorous analysis of their experience in the Gülen Movement.

14 I argue that the concept of soft power can be considered as a "category of practice" (used by actors in everyday settings to make sense of themselves, of their activities, of what they share with, and how they differ from, others). However, it cannot be accepted as a "category of analysis" (the "experience-distant categories used by social analysts" in an academic context) (Brubaker, Cooper 2000). In an effort to go "beyond the concept of soft power", I will stress the complexity of situations of influence, types of actors and interactions between them. The relations between Turks and Africans in a situation where the Turkish actors try to gain influence over Africans will be at the centre of the article.

Here I intend to show how the strategy of influence developed by a private actor such as the Gülen Movement whose members are moved by their own agendas can be reappropriated, re-interpreted by African individuals that experience their own trajectory from Africa to Turkey in this movement. To do so, I will rely upon a microlevel study of the migration of African students to Turkey who came through the channel of the Gülen Turkish schools in Africa to pursue their studies in Istanbul.

The methodology used is a qualitative one with interviews with seventeen African students or former students who came to Istanbul through the GM: three from Nigeria (a man and two women), eight from Senegal (five women and three men), two men from South Africa and three men from Kenya. Sixteen of the interviewed were schooled in a university close to the Gülen Movement (Fatih University) which includes in its ranks students who just finished the Gülen secondary schools all around the word ${ }^{5}$. In the framework of my PhD thesis research in Kenya, South Africa, and Senegal I developed connexions with African students in Fatih University. The Nigerian students are the main African group of students in Fatih University (along with Malians) and I met them while socializing with other African students and attending social events in the university. All those students had just finished high school when they first arrived in Istanbul. When interviewed, they were between 19 and 26 years old (one of them had already graduated and was a businessman in Istanbul by that time) at undergraduate or post-graduate levels in scientific, information and communication technologies and management areas (which is the speciality of Fatih University). Most of the interviews were informal, given that interknowledge networks had brought us together. Participant observation has also been conducted in the Light Houses ${ }^{6}$ of Istanbul, apartments where students of the Gülen movement stay together. I was invited to stay over at some Light Houses for female students (since gender separation in home spaces is strict in the Gülen Movement) and also attended events where the "African community" would gather as such in the public spaces of the university. This research was carried out between 2011 and 2014.

17 I argue that unlike the preconceived idea that any education would be both a sign of attractiveness and a source of ability to shape other's countries desire in the way the 
Turkish state would want to (what a soft power type of analysis would conclude), the migration of African students to Turkey through the Gülen Movement represents a real challenge for the Gülen movement itself. Furthermore, it would even represent an obstacle in its strategy of influence on African elites and on the deepening of Turkey's collaboration with them.

\section{The Role of the Gülen movement in African students' mobility in Turkey}

18 First of all, I will describe the factors through which African students schooled in a Turkish school in their country of origin decide to come to Istanbul in order to pursue their university studies?

\section{Reaching elite families}

19 Turkish schools are established in around 40 African countries. The school fees are high (between 3,500 and 8,500 euros per year with boarding in the studied countries ${ }^{8}$ ) allowing the schools to recruit children from rich families (to which can be added a proportion of students receiving a scholarship on a criterion of excellence). African parents send their children to these schools because of their very effective preparation for national exams based on a very competitive conception of education.

As a university professor and a member of the Board of the Gülen Movement's schools in South Africa puts it during an interview in Johannesburg:

The people we are targeting are going to be important political leaders or businessmen. By educating them and making them respectful human beings with a sense of responsibility they will behave well with their inferiors who will do so with their inferiors and so on. ${ }^{9}$

21 This relies upon a pyramidal conception of society and an elitist vision of social progress. From a strategic organizational perspective, imposing such high fees furnishes economic resources for the schools to grow (schools are part of non-profit organizations where the money earned aims at expanding the network of schools). As one of board member of the South African network puts it "If we chose to open charity schools we would open one school in each country. Since it is private, we can open ten schools instead of one". But above all, the objective is to target potential economic and political resources through the African students. Indeed, this strategy provides a direct access to a number of rich African families, most of them active in business or politics that are very useful resources for the Gülen movement. For example, the father of a Senegalese Turkish school student is doing both politics and owns one of Dakar's football teams. The Senegalese businessman and Turks of the Hizmet in Senegal have been doing business and he is now renting the field over which the new school of Dakar has been built. Lastly, it provides a link with the future elite of the African country and some access to resources. As an important figure of the Gülen Movement in Istanbul states:

of course we tend to reach rich and remarkably clever people. Because their reach within the society will be wider than the reach of a taxi driver or a bakkal owner for instance. If we can touch them, we can also touch more individuals. These people will have influence. ${ }^{10}$ 
Having an influence over local elites is a way to spread the movement's values but also to obtain facilities (in infrastructures, business, political support, etc.).

\section{The strategic ambiguity in the African settlement}

Joshua Hendrick defines the Gülen Movement as a "graduated network of affiliation" structured in different circles. These circles correspond to different degrees of adhesion to the values of Fethullah Gülen and of commitment to the social actions of the movement. The most central circle is the Cemaat, the hierarchized circle at the core of the community. The second one is constituted by the Arkadaşlar, a large network of devout persons living according to the teachings of Fethullah Gülen. Then come the Sympathizers, supporters of the action of the Hizmet who participate from time to time in activities organized by the movement to support them. Last but not least, the consumers are those individuals who, sometimes without even knowing it, "buy" products of the GM's (education, business) for the mere reason that they are the best available in a competitive market place.

Fig. 1. Different degrees of commitment and adhesion in the GM as presented by Joshua Hendrick

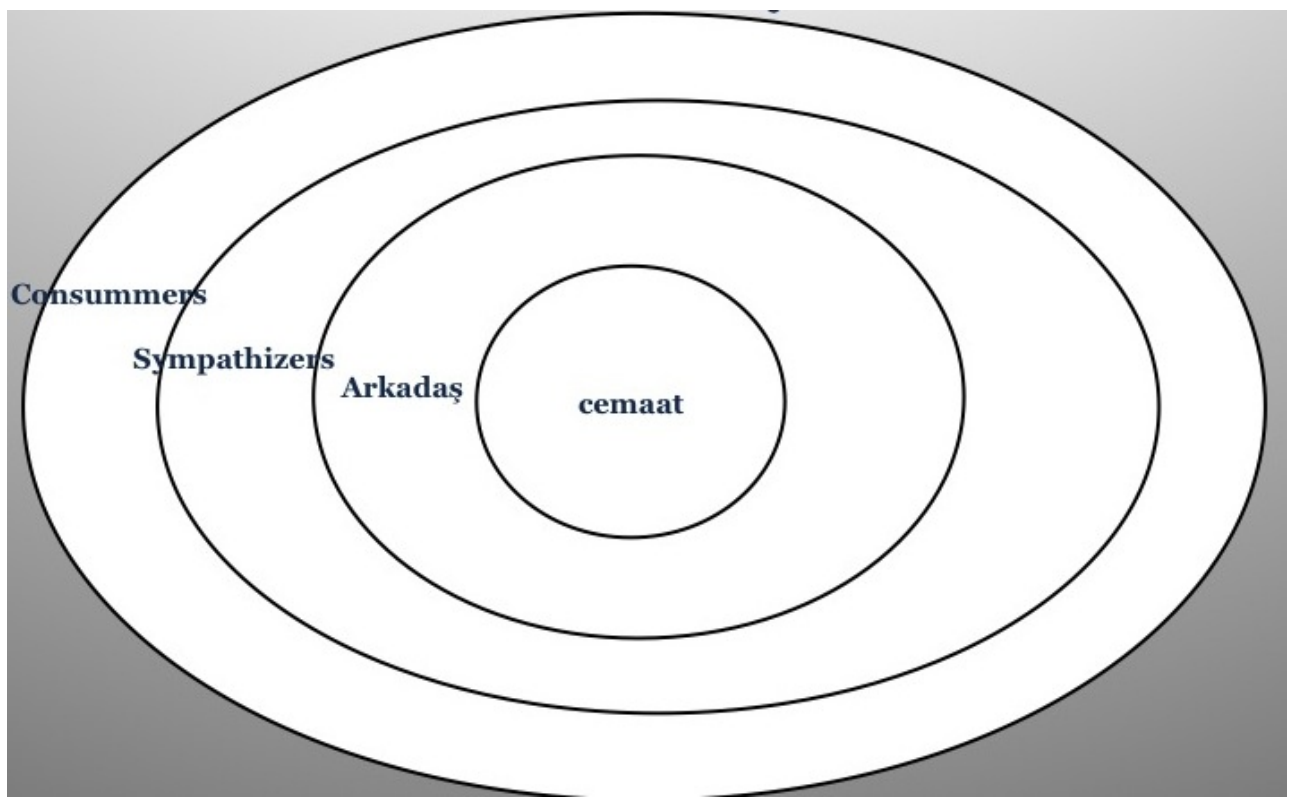

"Strategic ambiguity" means members of the Gülen Movement would adopt different practices and discourses according to the different circles of sociability they are in. " The Gülen Movement network mobilizes in accordance with an ambiguous prescription of action (aksiyon) which allows its followers to consistently redefine their identity to meet any obstacles or challenges that might arise" (Hendrick 2012: 207). According to the location of an individual in the circles, there is a change of discourse and practices that characterizes the "strategic ambiguity" of the GM as a whole. This is the scheme on which the Gülen Movement based its expansion. It is one of the reasons why our research reveals most of the African students coming to study in Turkey did not know of Fethullah Gülen before coming to Turkey and had no idea of the existence of a vast network of followers over the world (see below).

Here I will examine the factors of African students' choice of mobility in Turkey. 


\section{The Gülen Movement's ability to attract through flexibility and transnational resources} "Actually, my dad sent me to the Turkish schools because they [the Turks from the Gülen Movement in Dakar] let him know that I could obtain a scholarship for university in a foreign country afterwards. And of course I wanted to go study in a foreign country. That's the thing in Senegal; we all wanted to go outside, to the States, Canada, and France. In Senegal it's almost compulsory if you want to work in a big company. My dad and I really wanted me to go to Canada. After my baccalauréat, I applied and even got accepted in a private university in Ottawa. But the fees were so high and the people in my [Turkish] school could only help us to go to Turkey. So at the last minute, I accepted the offer to go to Istanbul'12".

31 Here we can see that unlike what is presented in Nye's theory, Turkey as a whole is not perceived as an attractive country. Instead, the students prefer Western countries' universities to pursue their studies. Even more, a private Turkish actor identified as such by the African students, the Turkish schools of the GM, is perceived as attractive because it might give them opportunities to study in the USA or Canada (but not Turkey which is never presented as a first wish by students). Entailed in a limited 
horizon of possibilities, African students reassess their projected career by accepting to go to Turkey. Here we can see the importance of the different local contexts and opportunities offered to students. As our field research revealed, much less students from South Africa came to Turkey to pursue their studies than Senegalese students. Indeed, the educational opportunities in South Africa are greater and provide different possibilities from selective quality public universities (University of Kwa Zulu Natal, University of Wits) to private universities. Asked about this issue, a teacher in South Africa stated "Of course for us it is tougher to send students to Turkey. Because in South Africa, there are many good universities, so students are not as eager to move as in other African countries ${ }^{13 "}$.

Secondly, one of the main reasons brought up by African students who came to Istanbul through the GM is the dedication of the teachers in their Turkish schools to persuade them to go to Turkey.

After her baccalauréat in the Turkish school of Dakar, a Senegalese girl, now a student in Istanbul, had first registered in the Senegalese university of Cheickh Anta Diop in medicine. "But we were more than 600 students in the medicine amphitheatre. While you know in Yavuz (the Turkish school in Dakar) they took too much care of us. So I was not used to it $t^{14 "}$. While she was hesitating to give up university in Dakar, she received a phone call from the human resource responsible of her former Turkish school offering to enrol her for the next semester in a Turkish university and to take care of all the administrative steps. She finally accepted and has been studying in Turkey for 4 years.

This brings us to another strength of the movement as a network positioned in different social spaces: it offers to take care of all the administrative steps such as getting a visa and enrolling in a Turkish university for the African students. It also offers to host them in dormitories or shared flats. To sum it up, the resources of the social transnational space constituted by the GM between its different countries of settlement and Turkey are used to organize the transfer of students. This is made possible not only through the dedication of the teachers who do the follow-up, but also through the network's ability to mobilize the resources of its transnationality from Africa to Turkey.

Lastly, when trying to encourage the parents to send their children to Turkey, the Turkish teachers in the Turkish schools of Africa may promote the image of Turkey as a Muslim conservative country, more appropriate than the Western countries for a student. Here when Turkish teachers in Africa try to persuade their Muslim students' parents to send their child to Turkey they promote an idea of good Muslim morality. Reportedly, Turkey is presented as the heir of the Ottoman Empire, a country of pious Muslims at the image of their action in Africa. Here they project a model of Turkey as an antithesis to Western countries (notably France and the USA), supposedly in moral decay $^{15}$.

When asked why she came in Turkey after studying in a Turkish school a Muslim female-student from Nigeria in Istanbul since 2011 answered:

I don't know, my dad convinced me. Because my dad says according to them in Turkey I would be in a country with an Islamic background. And my dad wanted me to have an Islamic background here. But of course it is the opposite here. Most of them here [the Turks of Istanbul] don't even pray, they don't really cover their heads. Here they have more of a European culture ${ }^{16}$. 

away from home. activism. Senegal, describes this discrepancy: different ways of life cohabitate.

Turkish teachers in Africa manage to create an image of good morality which is reassuring for parents when they have to take the decision of sending their children

Criticizing the vision of Nye concerning academic institutions as a source of soft power, Todd Hall, associate professor of International Relations at Oxford University explains, "it is difficult to parse out attraction from other possible mechanisms" (Hall 2010). Indeed, as demonstrated, the choice to study in Turkey for African students results more from the strength of the network format of the Gülen Movement and from the field of possibilities in which the African students are embedded than from an attraction towards Turkey and its education system.

Furthermore, we can question another aspect of Nye's theory according to which each country would promote a fixed set of what constitutes its "values" to enforce its soft power. Attaching specific sets of values to a country (as Nye did with the USA, whose soft power would come from the values of democracy and liberalism it embodies and promotes) in a normative way, blurs the reality of the competition of different groups for the definition of a nation's values. In Nye's literature, soft power is sometimes "employed to advocate and justify a certain set of values and a specifically liberal conceptualization of American identity as central to US international power" (Hall 2010: 196). Similarly, the soft power literature concerning Turkey tends to essentially associate with Turkey a specific set of values (changing according the time and the authors) such as Turkey as a model of "laïcité" for the Muslim countries or in the 2000s, Turkey as a synthesis between capitalism, democracy and Islam ${ }^{17}$. Yet, values are promoted by different groups (state and non-state actors) with their own framings and conception of what is considered as good and evil, and an ideal society and their own agendas. There is no essential set of values that would characterize Turkey. Instead, different Turkish groups (various state actors -the army or the foreign ministry -, and civil society actors - business associations, NGOs and religious networks like the Gülen movement) are trying to promote abroad political values they associate with Turkey according to their own agenda. In the case of the GM, promoting Turkey as a conservative Muslim country to the Muslims students' parents is a way to attract them to Turkey. It also corresponds to the ideal of the core followers of Fethullah Gülen in Turkey as the cradle for an Islam based on self-sacrifice, community and social

As we see, this African student who later on discovers Turkey has a fairly different experience of what she perceives as Turkish culture.

D., a former Senegalese student in Istanbul, now working in a Turkish school in Dakar,

The fact that many students have difficulties in Istanbul is due to the discrepancy you see there in Istanbul. On the one side, they [the Turks from the Light houses in Istanbul] are very strict, very conservative, which would be okay for us. But on the other side, we can see that apart from the Hizmet [named given by the followers of the GM to their group], the Turks don't live this way. They drink, smoke and all. We don't want it but it's just that they impose a frame to us and we can see that people are not really living like this in Turkey. I mean in Istanbul at least. ${ }^{18}$

This student describes the experience, necessarily out of phase with the vision promoted by the Turks in the Senegalese school, of a complex Turkish society in which 


\section{The African students' trajectory from the margins to the core of the GM}

43 The success of the movement is demonstrated through its ability to channel an African elite, with a strong economic potential, to Turkey where it will be schooled in universities close to the movement. The students pass through the transnational social space of the Gülen Movement experiencing the different circles of sociability of the movement.

\section{The movement from the consumers to the core of the GM}

In their country, African students are part of the fourth circle corresponding to the consumers. They enrol in a Gülen school because it "is the best available in a competitive market place". This idea is confirmed by interviews led both in the schools in Kenya, South Africa and Senegal and in Turkey with African students showing that most of them did not even know of Fethullah Gülen until they came to Turkey ${ }^{19}$. Once arrived in Istanbul, the African students channelled through the GM get closer to the core of the GM, since they are included in the circle of sociability of the Arkadaşlar, those devoted friends of the GM (yet not pertaining to the decision-making group of the movement, the Cemaat). As a South African student in Istanbul puts it, "That's only when we arrived here [in Istanbul] that we realized the big machine we were into". In Istanbul, the students are indeed entirely socialized into the core of the movement's activities.

As part of the strategic ambiguity, the existence of different circles of sociability also implies a variation in the practices and discourses in the Gülen Movement itself. While they were still in Africa, the Turkish teachers playing the role of intermediaries between Africa and Turkey informed them that they could be offered housing in Istanbul, which most of them accepted easily. Once arrived, students discover a rather constraining context. A conservative life organization is much more strongly imposed in the Arkadas circle of the movement than on its fringes. First of all, the housing furnished to the African students is mostly Light Houses (Ișık Evleri). Funded according to Gülen's recommendations, these are places for the students to live according to Muslim values. They are conceived as a protective cocoon for Muslims against a decaying Turkish society. In the GM's Light Houses, every foreigner has to share his flat with 3 to 4 other Turks so that he is encouraged to learn Turkish quickly. Then, the students have to conform the strict gender separation promoted inside the Arkadas, circle of the movement according to which houses are gender separated and any mixed social activity is strongly discouraged inside or outside the university. The curfew is at $6 \mathrm{pm}$ (in general, there is a certain room for manoeuvre in the different houses) and internet is forbidden (even though every student now has it on his cell phone). At last, the Muslim students from Africa are encouraged (even if it is not compulsory) to pray 5 times a day and are enticed to join the lecture camps where Nursi and Gülen's books are read. These rules are enforced by the abi (old brother) or abla (old sister) ${ }^{20}$ who look after their fellow students in each house.

What's more, most of the students attend universities close to the Gülen Movement in Istanbul, such as Fatih University or Süleyman şah University which have agreements with the Turkish schools all around the world, which explain why most of the African 
students are directed towards them. In these universities, a lighter yet still present social control is enforced, leaving them limited spaces for other types of behaviours.

As a consequence, when coming to Turkey, the students experience a change of position from the "Consumers" to the "Arkadașlar" circle of the movement which provokes strong reactions from the African students. This is a negative consequence of the "strategic ambiguity" of the movement due to an imbalance of information between what African students expected and what they are confronted with when they arrive in Turkey. This informational imbalance strengthens the opposition reactions of African students (see below "African students' reappropriation and diversions").

In Istanbul, during the preparation meeting of the festival "This is Africa" organized by African students of Fatih University to promote Africa in their school, one of the African students expressed himself on the debate over extra-school activities which are always separated between men and women, as the rest of the African students complained. He declared: "We have to be able to adapt to this country and to this university. By accepting to come here we knew what to expect". Interestingly enough, the rest of the African students in the public, answered vigorously "No, precisely, that's what we did not know! That's the point". Eventually, the speaker corrected himself and admitted they [African students] might not have been aware of the way of life they would be imposed in Istanbul, but that still now that they were here, they should adapt ${ }^{21}$.

I would argue that the strategic ambiguity of the movement is a problem in the attempt to "transfer" African students from the local African space in which they are only consumers of the GM into the Turkish space where they are expected to become active members of the GM.

Here again, the Christians students, coming from Africa through the Turkish schools to Turkey should be differentiated. First of all, their number is, according to my research in Fatih University, very limited (a few from South Africa and from New-Guinea). According to the testimonies, this would not be due to a discriminating approach by the Turks in their schools in Africa, but rather to a self-limitation of the students themselves who identify Turkey first of all as a Muslim country and are less attracted. Then, the Hizmet Abi and Abla seem to try to find a negotiating way for the nonMuslim students who arrive in Turkey. Non-Muslim students are offered to learn more about Islam, they are enticed to join the reading camps but are not compelled to convert and to pray ${ }^{22}$.

51 As a Muslim Senegalese male student sums it up: "I think with the Christians they [the Turks from the Hizmet] don't really know how to behave. Generally they are cooler with them. The Christians are freer than we are. They accept behaviours from them that they would never tolerate from us, that's for sure! ${ }^{23 "}$.

\section{Strategies and tactics in the integration of African students in the Gülen Movement}

Sending students from Africa to Turkey is interesting from the point of view of the GM since the inclusion of outside elites in its ranks is a way for the movement to keep growing beyond Turkey's borders. 


\section{Producing its own local African intermediaries}

insertion of the GM in Sub-Saharan Africa seems to have a limited success. Interestingly enough, the African students are not offered to circulate even in the African space, where circulation of teachers is still limited to Turkish members of the Gülen movement or Central Asians. The Central Asian former students, one of the regions where the Gülen schools have been organized for the longest time and where an historical and cultural common history is shared, tend to play a large role in the ranks of the Gülen missionaries all around the world. While African students, arguably only for pragmatic management reasons (the Turkish missionaries still need to have African intermediaries in the schools) are still only directed to their country of origin. of

European Journal of Turkish Studies, 21 | 2015 
course, other questions could be raised: the matter of cultural distance, the racial frontier. But we cannot say anything conclusive on this topic, and can only stick to the observation that for now, African students are only offered a limited possibility of social promotion in the Gülen movement.

Consequently, African students tend to re-appropriate or even divert the frameworks in which they are put.

\section{African students' reappropriation and diversions}

The African students arriving in Istanbul realize the informational imbalance in the GM. Indeed they went from a consumer role, where they had no awareness of the existence of the Gülen movement, to a central circle of the movement with the highest level of constraints on their life. Meanwhile, they also notice that the only career proposed to them is a local carrier for the Hizmet movement back in their country of origin, and that there is no possibility of social promotion for them in the Gülen Movement's transnational social space. What's more, Africans also have their own projects for themselves in their country of origin or in Turkey, taking into account that most of them come from wealthy families providing them with social and economic capital which widens their horizon of possibilities.

Consequently, the African students tend to express their discontent and convert the constraints of their experience into resources. By this I mean, they implement tactics (Certeau 1984) in order to reappropriate some power relations:

I call a 'tactic,' [...], a calculus which cannot count on a 'proper' (a spatial or institutional localization), nor thus on a border-line distinguishing the other as a visible totality. The place of a tactic belongs to the other. A tactic insinuates itself into the other's place, fragmentarily, without taking it over in its entirety, without being able to keep it at a distance. It has at its disposal no base where it can capitalize on its advantages, prepare its expansions, and secure independence with respect to circumstances. [...] because it does not have a place, a tactic depends on time - it is always on the watch for opportunities that must be seized 'on the wing.' Whatever it wins, it does not keep. It must constantly manipulate events in order to turn them into 'opportunities.' The weak must continually turn to their own ends forces alien to them (Certeau 1984: XX).

In the framework of this new environment in which African students are immersed with its own unknown codes, Africans are going to invent tactics, seizing opportunities in their everyday life in the Gülen Movement's Istanbul to renegotiate their position. To describe their varied behaviors, I shall use the typology proposed by Albert 0 . Hirschman (1995), in which the different types of demonstration of discontent in an organization are categorized. He presents exit, voice and loyalty as three possible conducts in case of disagreement or dissatisfaction. I added the category of "exit with benefits" as a fourth possible conduct.

Exit consists in the silent demonstration of discontent by leaving a social group. Numerous students coming from Turkish schools in Africa decide to leave the movement totally.

A 20 year-old Nigerian female student in Bahçeșehir University decided to leave the Light House and then the whole movement after only a week:

I just kept crying and crying because I was afraid to be alone [She was the only Nigerian in the house and the other Turks were not speaking good English] and 
they were controlling everything I was doing. It was too much. So I just decided to register in the dormitory of my university, here in Istanbul. At first they were calling me to try to make me take part to the activities they even called my dad to scare him, saying that I would not be able to manage by myself in Istanbul. But now they totally gave up and I have literally no contact whatsoever with the movement.

26

This student, coming from a wealthy family quickly decided to get out of the Light House, where she felt the constraints would be too heavy. Through a Nigerian friend she got to know in the university she decided to take her independence extremely quickly and cut the contacts with the movement. As we can see, she came to Turkey through the movement, which persuaded her to come and helped her with her application process for university and the visa but then decided to get out of the movement, which could easily be done since her family was rich and her dad supported her choice.

What I call "Exit with benefits", is a progressive exit from the movement while using the resources it can procure for the construction of one's own career. Africans can use the resources proposed by the GM in Turkey in order to prepare their future exit from the movement.

67 The following profile corresponds to a Senegalese male former student. During his university studies, this student slowly took his distance from the movement, left the Light House until cutting every contact with the core of the movement at the end of university. But he used the network of businessmen he met and his knowledge of the Gülen movement's economic institutions like TUSKON to be hired in an African company located in Turkey. He used the resources he could access through his experience in the GM (learning language, economic networking) that he developed patiently for years in the prospect of making a career for himself. ${ }^{27}$

Many students are in this same situation. Very few of them abruptly leave the movement after a few months only. Most of them keep a link with the movement even if they leave the Light Houses (which is very common in the African students' community). They take part in the business summits organized by TUSKON as translators, for instance. While progressively leaving, they take advantage of the networks and resources made available to them in Turkey by the Gülen Movement.

Hirschman defines Voice as an individual or collective protest aiming at changing the organization or one's position in the organization from the interior.

A rich Senegalese student in Fatih University refused to pray and did not respect the curfew. As a strategy to impose her desire for more freedom, she threatened to call her father, with whom the Turks from the Turkish schools are doing business in Senegal. The supervisor of their flat was afraid that she would complain and tarnish the reputation of the Turkish schools and teachers in Dakar. They decided to let her be. She is the only girl I know in all the Light Houses provided with a single bedroom and a more flexible curfew. ${ }^{28}$

Here exit and voice can reinforce each other. Indeed, to be really efficient, the voice strategy must be coupled with the threat of exit (Bennani-Chraibi 2009). This case is extremely relevant since it shows the negotiations of power between Turks and Africans using the different territories of the movement. This student used her powerful family in Senegal to re-establish a balance of power with the Turkish members of the GM she is in contact with in the Light House of Istanbul. By playing the 
card of "the movement's image in Senegal" she managed to secure a comfortable position for herself in Turkey. She converted her social capital in Senegal in the Turkish space using it as a threat.

The fourth type of conduct in the case of discontent is loyalty. Loyalty reveals a feeling of faithfulness and duty towards the organisation.

A Senegalese female student in Fatih University, who at the time of the interview had been in a Light House for 3 years states:

I decided not to do anything. I decided I would rather participate and try to benefit from the experience, you know. Even if some aspects annoy me I am not as angry as others [other African students]. And they [the abla from her house] lately asked me if I wanted to be an abla (Angey forthcoming). I still hesitate because I know that they [the Turks from the GM] don't give you anything without asking you for something in return. At first I was really criticizing them, but you know they have good ideas and good people in here, it is just that sometimes their actions, the way they behave are wrong. But that's because they don't know much. ${ }^{29}$

Most of the students interviewed resort to this type of behaviour. They stay in the movement which bring them comfort (housing and food is paid for by the businessmen of the GM), a securing circle of sociability (many African students if they are critical of the project of the Light Houses tend to highlight the personal bonds created with Turks of their Light House) and at the same time find spaces to express their discontent when they are with other African students with whom they socialize a lot once they are out of their house (in the university or in cafes).

Finally, I shall describe the success of integration of some African students. Some of them agree to become local intermediaries in their local African space of origin. In this case these former students do not only decide to stay loyal to the movement but they express a positive experience in the movement. Most of them acknowledge awkwardness from the Turks taking care of the Light Houses but find justifications for it.

As D., now a teacher in Dakar puts it:

I cannot complain. They were harsh sometimes, but for me it was normal, I was Muslim myself so had no problem with the religious duties we had. And I think it was my education, but I thought that it was normal they were strict. It was the same at home in Dakar so I guess that's why I adapted. And also this curfew thing I can understand, because in Istanbul there are lots of drugs and everything. So the early curfew was for our safety that's all. ${ }^{30}$

A significant part of these students agreeing to become local intermediaries for the GM (but certainly not all of them) corresponds to former grant-holder students of the Turkish schools in Africa, from poor origin. They fell indebted to the GM for the help they received and accepted a position in the Gülen Movement where they become local intermediaries. Bourdieu and Saint-Martin (1982) talk about "oblats" in the Christian Church: these young people from poor origins who are put in the Church early and dedicate their life to it because they feel they owe the movement their life. This is the case for the following profile.

D.C., a 30 years-old Kenyan teacher corresponds to this profile. A very good student from a modest family, D.C. had studied in the public school of Nairobi until high school when he was recruited by the Gülen school of the Light Academy with a scholarship according to his results in a national exam. In 2004, D.C. was proposed to study in Haceteppe Ankara with a movement scholarship. He was then offered a job as a 
professor in a secondary school in Nairobi. In the interview, D.C. kept expressing his gratitude to the Hizmet, explaining that he could not have studied for such a long time and discover the world if he had not been contacted by the Gülen Movement when he was 15 years old ${ }^{31}$.

\section{Circulation and blockings}

79 The GM's opening to African students is a challenging experience for the GM since it brings to light the limits of its strategy of expansion. Indeed, the lack of information on the reality of the movement and the rigidity of its core structure where practices and discourses differ from the one in the fringe circles create reactions of opposition that are counter-productive in the objective of the GM to spread its influence over the future elite of African countries. Beyond this, however, lies the question of the strategy of development of the GM: the "strategic ambiguity", which characterized the movement's adaptability and allowed it to grow by using different discourses and practices according to the places in order to reach a much wider population than those of the faithful followers of the Cemaat. This is the biggest strength of the movement but might also become its biggest limit: How to integrate foreigners in such a movement?

Above all, our analysis tried to show the limits of the concept of soft power for characterizing a concrete situation of influence of a Turkish private actor in Africa and the theoretical bias it implies.

First, opposing the idea of passivity of African recipients of a Turkish soft power in the form of the Gülen schools, students arriving in Istanbul will put into motion "tactics" in order to bypass, negotiate or reappropriate the strategies of management of the Gülen movement. Here the fact of possessing economic and social capital seems critical for the terms in which students agree to play the institutional game of the movement.

Then, in terms of the precision of the term 'soft power', the idea that every initiative led by a private or public actor would necessarily promote Turkish soft power, also has to be questioned. Indeed, our case study, without denying the link with the AKP in the Turkish schools' expansion, shows here most of all a private group's own strategy of expansion, in which organizational stakes come first, even though their effects tend to go against the interest of Turkish state in the long run (since students refuse to "play the game"). Reciprocally, the latest crisis opposing Erdoğan's government to the Gülen movement exemplified in a very striking manner how much Turkey's strategies of power abroad are the result of different social groups which can collaborate during certain periods (as was the case for the AKP and the Gülen Movement until December 2013) and then oppose each other violently in other periods (as it has been since then). This has been to the point that the Turkish government leads a campaign of lobbying on African states to push them to close the Gülen schools (known as the Turkish schools in Africa), an initiative that is clearly threatening to weaken Turkey's representation abroad (Maasho 2015), contradicting furthermore the relevance of a single and vague "Turkish soft power".

83 At last, the idea that the attractiveness of Turkey would be increased by the Turkish schools in Africa has not been confirmed by the field research. If those schools manage to channel students to Turkey or a Turkish university, it appears that they do so because of a curtailed horizon of possibilities, in a period where worldwide mobility has 
never been so constrained for Africans, rather than by the supposedly growing attractiveness of Turkey, which is impossible to measure.

\section{BIBLIOGRAPHY}

(2011). L'Afriqueetsespartenairesémergents, Perspectives Économiques en Afrique, URL: www.africaneconomicoutlook.org/fr/thematique/emerging-partners/.

Agai, Bekim (2004). Zwischen Netzwerk und Diskurs, Bonn, EB-Verlag.

Altunışık, Meliha Benli (2005). “The Turkish Model and Democratization in the Middle East," Arab Studies Quarterly 27 (1/2) pp. 45-63. URL: http://media.library.ku.edu.tr/reserve/resspring12/ intl552_MSomer/week12.pdf.

Altunışık, Meliha Benli (2008). “The Possibilities and Limits of Turkey's Soft Power in the Middle East,” Insight Turkey 10 (2), pp. 41-54. URL: http://file.insightturkey.com/Files/Pdf/ insight_turkey_vol_10_no_2_2008_altunisik.pdf.

Angey, Gabrielle (2014). « La recomposition de la politique étrangère turque en Afrique subsaharienne. Entre diplomatie et acteurs privés ", Notes de l'Ifri, mars 2014, pp. 1-34. URL: http://www.ifri.org/sites/default/files/atoms/files/032014angeyafriqueturquie.pdf.

Angey, Gabrielle (forthcoming). « L'éthique missionnaire de l'éducation dans le mouvement de Fethullah Gülen en Afrique subsaharienne », Social Science and Mission.

Balc1, Bayram (2003). Missionnaires de l'Islam en Asie centrale. Les écoles turques de Fethullah Gülen, Paris-Istanbul, Maisonneuve et Larose-IFEA.

Balc1, Bayram (2014a). "What Are the Consequences of the Split Between Erdoğan and Gülen on Turkey's Foreign Policy?,” Foreign Policy Journal, January 17, 2014. URL: http://

carnegieendowment.org/2014/01/17/what-are-consequences-of-split-between-erdogan-andg\%C3\%BClen-on-turkey-s-foreign-policy.

Balc1, Bayram (2014b). “The Gülen Movement and Turkish Soft Power," Carnegie.fr, Febbruary 4, 2014. URL: http://carnegieendowment.org/2014/02/04/g\%C3\%BClen-movement-and-turkishsoft-power

Bastian, Jean-Pierre; Champion, Françoise; Rousselet, Kathy (2001). La globalisation du religieux, Paris, L'Harmattan.

Bava, Sophie; Gueye, Cheikh (2001). « Le grand magal de Touba. Exil prophétique, migration et pèlerinage au sein du mouridisme », Social Compass 48 (3), pp. 421-438. DOI:

10.1177/003776801048003008.

Bayart, Jean-François (1999). «L'Afrique dans le monde : une histoire d'extraversion », Critique internationale 5, pp. 97-120. DOI: 10.3406/criti.1999.1505.

Bourdieu, Pierre; Saint-Martin, Monique de (1982). « La Sainte Famille : l'épiscopat français dans le champ du pouvoir ", Actes de la Recherche en Sciences Sociales 44-45, pp. 1-53. DOI: 10.3406/arss. 1982.2165. 
Brubaker, Rogers; Cooper, Frederic (2000). "Beyond Identity," Theory and Society 29 (1), pp. 1-47. URL: http://www.sscnet.ucla.edu/soc/faculty/brubaker/Publications/18_Beyond_Identity.pdf.

Bennani-Chraibi, Mounia (2009). "Exit, voice, loyalty,” in Olivier Fillieule (éd.), Dictionnaire des mouvements sociaux, Paris, Presses de Sciences Po (Références), pp. 228-235.

Çandar, Cengiz (2009). “Turkey's ‘soft power' strategy: A new vision for a multi-polar world,” Foundation for Political, Economic and Social Research, SETA Policy Brief 38. Retrieved from http://setadc.org/pdfs/SETA_Policy_Brief_No_38_Turkeys_Soft_Power_Strategy_Candar.pdf

Certeau, Michel de (1984). The practice of everyday life 1, trans. Steven Rendall, Berkeley-Los Angeles, University of California Press, 1984.

Daftary, Farhad (2003). Les Ismaéliens, Histoire et traditions d'une communauté musulmane, Paris, Fayard.

Fourchard, Laurent; Mary, André; Otayek, René (éd.) (2005). Entreprises religieuses transnationales en Afrique de l'Ouest, Paris, Karthala.

Granovetter, Marc (1973). "The Strength of Weak Ties," American Journal of Sociology, 78 (6), pp. 1360-1380. URL: https://sociology.stanford.edu/sites/default/files/publications/ the_strength_of_weak_ties_and_exch_w-gans.pdf.

Hall, Stuart (1973). "Encoding/Decoding in the Television Discourse," Paper for the Council of Europe Colloquy on "Training in the Critical Reading of Televisual Language," Birmingham Centre for Cultural Studies, University of Birmingham, in S. During (ed.), The Cultural Studies Reader, London, Routledge, pp. 507-517. URL: https://faculty.georgetown.edu/irvinem/theory/ SH-Encoding-Decoding.pdf.

Hall, Todd (2010). “An Unclear Attraction: A Critical Examination of Soft Power as an Analytical Category," The Chinese Journal of International Politics 3, pp. 189-211. DOI: 10.1093/cjip/poq005.

Hendrick, Joshua (2012). Globalization and Marketized Islam in Turkey: The Case of Fethullah Gülen, PhD dissertation, University of California.

Hendrick, Joshua (2013). Gülen: The Ambiguous Politics of Market Islam, New York, NYU. Press. Hibou, Béatrice (1999). La Privatisation des États, Paris, Karthala.

Hirschman, Albert O. (1995). Défection et prise de parole. Théorie et applications, Paris, Fayard.

LeBlanc, Marie-Nathalie; Meintel, Deirdre (2003). « Le religieux en mouvement », Anthropologie et Sociétés 27 (1). URL: http://www.erudit.org/revue/as/2003/v27/n1/index.html.

Maasho Aaron (2015). “Turkey's Erdogan seeks closure of Gülen-linked schools in Africa," Reuters American Edition, 01.22.2015. URL: http://www.reuters.com/article/2015/01/22/us-ethiopiaturkey-erdogan-gulen-idUSKBNOKV1MA20150122.

Mayrargue, Cédric (2009). «Pluralisation et compétition religieuse en Afrique Subsaharienne. Pour une étude comparée des logiques sociales et politiques du christianisme ou de l'Islam », Revue Internationale de Politique comparée 16, pp. 83-98. DOI: 10.3917/ripc.161.0083.

Nye, Joseph S. (2005). "Soft Power and Higher Education," Forum for the Future of Higher Education (Archives), pp. 11-14. URL: https://net.educause.edu/ir/library/pdf/FFP0502S.pdf.

Nye, Joseph S. (2004). Soft Power: The Means to Success in World Politics. New York, Public Affairs. Nye, Joseph S. (1990). Bound to Lead: The Changing Nature of American Power, New York, Basic Books. Otayek, René; Soares, Benjamin (éd.) (2009). Islam, État et société en Afrique, Paris, Karthala. 
Özdalga, Elizabeth (2000). "Worldly asceticism in Islamic casting: Fethullah Gülen's inspired piety and activism," Critical Middle Eastern Studies 9 (17), pp. 83-104. DOI: 10.1080/10669920008720169.

Özdalga, Elizabeth (2005). "Redeemer or outsider? The Gülen Movement in the Civilizing Process," The Muslim World 95 (3), pp. 429-446.

Roy Olivier (2002). L'Islam mondialisé, Paris, Seuil, 2002.

Tittensor, David (2014). The House of service, Oxford, Oxford University Press.

Turam, Berna (2006). Between Islam and the State: the politics of engagement, Stanford, Stanford University Press.

Van Bruinessen, Martin (2014). "The Netherlands and the Gülen Movement," Sociology of Islam 3-4, pp. 165-187. DOI: 10.1163/22131418-00104004.

Yavuz, Hakan (2003). Islamic Political Identity in Turkey, New York, Oxford University Press. Yavuz, Hakan; Esposito, John (2003). Turkish Islam and the Secular State: the Gülen Movement, Syracuse, Syracuse University Press.

Zaman (March 17, 2013). “Türk okulları, dış politikanın en önemli aktörü,” Zaman. URL: http:// www.zaman.com.tr/dunya_turk-okullari-dis-politikanin-en-onemli-aktoru_2066201.html.

\section{NOTES}

1. Concerning the Gülen/Erdogan crisis, see Balcı (2014a; 2014b).

2. Hizmet, meaning "the service" in Turkish, is one of the higher duties of Islam. The followers of Gülen call the GM the Hizmet. When referring to the Hizmet as the religious group, capital letter will be used, while the hizmet, as a duty is written in small letter. About neo-brotherhoods, see Roy (2002: 127).

3. A first attempt has been done briefly and unsatisfyingly by Tittensor (2014) in its chapter 4 "Voices from within, voices from without".

4. The three evils of humanityaccording to Said Nursi.

5. The other one was left in another private university not pertaining to the movement, but was socialized in the religious group.

6. Ișık evleri ("Light Houses") are apartments for students to stay where they can learn the teachings of Fethullah Gülen and lead their lives according to his principles.

7. Istanbul is the main destination for African Students from the Gülen Movement, but they are sometimes directed to other cities in Turkey where Universities close to the Gülen Movement exist such as Zirve Üniversitesi in Gaziantep. Our field research only focuses on Istanbul.

8. 8,500 euros in Nairobi, 3,500 euros in Johannesburg and 4,000 euros in Dakar for school fees and boarding for the year 2015/2016.

9. Interview conducted in Turkish, Johannesburg, October 9, 2013. Translation by the author.

10. Interview conducted in Turkish, Istanbul, March 10, 2014. Translation by the author.

11. Interview conducted in French, Istanbul, June 11,2013. Translation by the author.

12. Interview conducted in French, Dakar, September 16, 2014. Translation by the author.

13. Interview conducted in Turkish, Istanbul, Marh 1, 2014. Translation by the author.

14. Interview conducted in French, Istanbul, February 20, 2013. Translation by the author.

15. Yet it should be noted that Turkish teachers in Africa do not only target Muslim students. During our research we met two non-Muslim African students (from South Africa) who decided to study in Istanbul thanks to the movement. According to them, Turkish teachers would not mobilize the same type of discourse when talking to the Christian students. 
16. Interview conducted in English in Istanbul, November 16, 2013. Translation by the author.

17. For a critical analysis of these discourses see in this EJTS issue, Yohanan Benhaïm and Kerem Öktem's article on Turkish soft power discourse.

18. Interview conducted in French, in Dakar, September 16, 2014. Translation by the author.

19. The Gülen Movement's expansion is indeed not based on a direct religious proselytism.

20. Abla means older sister. It is used in the GM presented as a metaphor of a family. It refers to persons of a higher status in the hierarchy of the movement. In the Light Houses, the abla (and abi for men) looks after the other people of the house, and makes sure they respect the proper principles of life in the house.

21. Participant observation led in Fatih University, Istanbul, March 27, 2013.

22. Two cases of conversions have been reported by students in Fatih University but unfortunately no interviews have been carried out with the converted yet.

23. Interview conducted in French in Istanbul, June 11, 2013. Translation by the author.

24. Interview conducted in English and Turkish, Istanbul, March 1, 2014. Translation by the author.

25. Ibid.

26. Interview conducted in English, Istanbul, March 6, 2014. Translation by the author.

27. Based on an interview conducted in French in Istanbul, June 11, 2014.

28. Based on participant observation led in Istanbul, March 22, 2013.

29. Interview conducted in French in Dakar, August 18, 2015. Translation by the author.

30. Interview conducted in French, in Dakar, September 16, 2014. Translation by the author.

31. Based on an interview conducted in English in Nairobi, May 26, 2011.

\section{ABSTRACTS}

This article will try to challenge the concept of soft power relying upon a case study of African students coming to Turkey through the channel of the Gülen Movement, a religiously inspired social movement. Through a micro-level analysis of African students' trajectories and experiences in the Gülen Movement, I will try to show the limits of the concept of soft power as a category of analysis showing that it is not only vague, but can also be proven wrong in its theoretical grounds.

\section{INDEX}

Keywords: education, Turkey, Sub-Saharan Africa, Gülen Movement, Soft Power

\section{AUTHOR}

\section{GABRIELLE ANGEY-SENTUC}

PhD candidate EHESS (CETOBAC), Paris

French Institute of Anatolian Studies (IFEA), Istanbul

angey.gabrielle@yahoo.com 